"Entrepreneurial education in the school curriculum: in search of positioning in Zimbabwe"

AUTHORS Gwendoline V. Nani

ARTICLE INFO

Gwendoline V. Nani (2016). Entrepreneurial education in the school curriculum: in search of positioning in Zimbabwe. Problems and Perspectives in Management, 14(3), 85-90. doi:10.21511/ppm.14(3).2016.08

DOI http://dx.doi.org/10.21511/ppm.14(3).2016.08

RELEASED ON Friday, 29 July 2016

JOURNAL

"Problems and Perspectives in Management"

FOUNDER

LLC "Consulting Publishing Company "Business Perspectives"

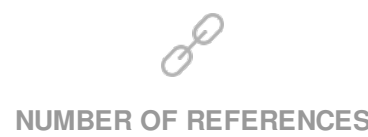

0

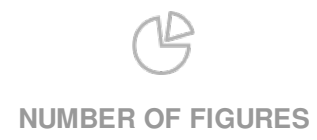

0

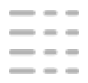

NUMBER OF TABLES

0

C The author(s) 2023. This publication is an open access article. 


\title{
Entrepreneurial education in the school curriculum: in search of positioning in Zimbabwe
}

\begin{abstract}
This study was conducted to find out when Entrepreneurship can be introduced in the school curriculum. A case study design premised in the qualitative approach was employed, which used semi-structured focus group interviews as data collection instruments. The areas of study were purposively selected government primary and secondary schools in the Bulawayo Metropolitan Province in Zimbabwe. Data were analyzed thematically and discussed according to research objectives. Findings revealed that Entrepreneurship per se is not taught in government primary and secondary schools. Based on these findings, the recommendations were that Entrepreneurship should be introduced in the school curriculum at primary level to allow learners to lay a solid foundation for creativity, nurturing and innovation of business ideas for use later in life.
\end{abstract}

Keywords: Entrepreneurship, practical subjects, foundational phase, nurturing, primary school. JEL Classification: M1.

\section{Introduction}

Much has been written about entrepreneurship, thus, showing its importance in the development of economies (Ali, 2015; Esene, 2015; Agboola, 2014; Udu \& Amadi, 2013; Nkechi, Emeh, Okechukwu, 2012; Akpan, Effiong \& Ele, 2012). Entrepreneurship is regarded by most countries to be the panacea to unemployment and poverty reduction, as the phenomenon of shrinking formal job opportunities continues to bite. It is in this regard that the Government of Zimbabwe has adopted practical subjects in its educational curriculum, as recommended by the 1999 Nziramasanga Commission. The aim is to produce graduates who can create their own jobs after leaving formal education. However, in the teaching of these practical subjects, learners are not taken through the whole process of entrepreneurship and small business management, rendering the entrepreneurial process incomplete.

Udu and Amadi (2013) assert that, in most countries of the world, concentrated Entrepreneurship programs are introduced in higher institutions whereas introducing the subject at primary level is believed to lay a good foundation for learners to acquire knowledge and skills that will help them to take life challenges. North (2002) concurs that young people should learn entrepreneurship at an early age to develop skills needed to identify viable business opportunities and eventually start their own business undertakings.

In the United States, Japan and South Africa, mechanisms have been put in place to ensure that learners can actively become involved in entrepreneurial activities which could nurture their entrepreneurial spirit (Brown, 2000; North, 2002).

(C) Gwendoline V. Nani, 2016.

Gwendoline V. Nani, Department of Business Management, National University of Science and Technology, Zimbabwe.
In Nigeria, a study was conducted by Udu and Amadi (2013) on the possibility of integrating basic Entrepreneurship studies into primary education curriculum. Findings of the study indicated that the introduction of Entrepreneurship studies in the primary school curriculum was a welcome idea by educators and entrepreneurs, as it would help to lay a solid foundation for future entrepreneurial development.

This researcher concurs that the teaching of practical subjects should not be an end in itself, but a means to an end. Learners should not only be equipped with practical skills, but should also be exposed to the transformation and utilization of these practical skills in setting up and running actual businesses from an elementary stage and not only at higher levels of education. When learners are mentored on how to set up and run businesses from an early age, the rate of failure might be reduced when these graduates enter the entrepreneurial world. This study was, therefore, conducted to find out when Entrepreneurship can be introduced in the school curriculum so that requisite entrepreneurial and small business management skills are inculcated, nurtured and embedded in learners' lives so that when these learners enter the market at whatever age, they become relevant.

\section{Background to the study}

Although the focus of this paper is not to debate about the pre-colonial educational curriculum in Zimbabwe, however, the historical background is essential to put the study into its proper perspective.

According to Moyana (1986) and Zvogbo (1994), there were two types of educational systems in the then Rhodesia (now Zimbabwe): the F1 and F2 systems. The F1 system was ushered in through the introduction of a New Education Plan in 1966 where only 12.5 percent black students who had passed Grade 7 examinations were enrolled in F1 schools. Students in F1 schools specialized in purely 
academic and theoretical subjects. Thirty seven comma five percent went to F2 schools, and the remaining $50 \%$ were thrown out of the educational system. Moyo (2013) and Nyathi (2013) who are former school heads acknowledged that the F2 type of education was predominantly biased towards practical subjects. This researcher is of the view that what perhaps lacked from the F2 system of education to make these learners entrepreneurs was that learners were not taught how to set up businesses using the acquired skills.

After independence in 1980, the Government of Zimbabwe revamped the educational curriculum in an attempt to integrate core (theory and academic subjects) and practical subjects, as recommended by the Nziramasanga Commission (1999). The aim of this commission was to create students with both an academic and technical inclination. Through the revisit of the Nziramasanga Commission (1999), the Government is in a way admitting that the former F1 type of education is not the best for the Zimbabwean market needs. The F2 educational system is being brought back in a revolutionized way. It, therefore, becomes paramount at this stage to define entrepreneurship and entrepreneurship education in order to put the study into its proper context.

\section{Entrepreneurship}

Despite the abundant literature on the subject of entrepreneurship, scholars, researchers, practitioners and even policy makers have failed to come up with one specific definition of entrepreneurship (Fatoki \& Chindoga, 2011; Salami, 2011). Nieman, Hough \& Nieuwenhuizen (2014) define entrepreneurship as the emergence and growth of new businesses. It is the process that causes changes in the economic system through innovations of individuals who respond to opportunities in the markets. From this definition, one can deduce that entrepreneurship is about identifying an opportunity, innovating and setting up a business. In the process, entrepreneurs create value for themselves and society. The implication is that if a business is not established, the process will be incomplete. According to Rwigema (2004), entrepreneurship is the process of conceptualizing, organizing, launching and through innovationnurturing a business opportunity into a potentially high growth venture. This definition again shows that entrepreneurship is a process that should, ultimately, result in the establishment of a business. Therefore, for purposes of this paper, the definitions of entrepreneurship by Nieman et al. (2014) and Rwigema (2004) were used.

If a school is said to be implementing Entrepreneurship, then, the whole entrepreneurial process has to be followed and that can be achieved if learners are exposed to the subject from an early age. Therefore, if Entrepreneurship is introduced at primary level, it will give learners the opportunity to go through the whole process, thus, laying a solid foundation for the setting up of sustainable businesses later in life.

An educational institution is an ideal place for nurturing a business idea through Entrepreneurship education. Isaacs, Visser, Friedrich and Brijlal (2007) define Entrepreneurship education as the purposeful intervention by an educator in the life of the learner to impart entrepreneurial qualities and skills to enable the learner to survive in the world of business. Fayolle (2009) cited by Arasti, Falavarjani \& Imanipour (2012) concurs and explains Entrepreneurship education as all activities aiming to foster entrepreneurial mindsets, attitudes and skills and covering a range of aspects such as idea generation, start-up, growth and innovation.

\section{Statement of the problem}

In Zimbabwe, Entrepreneurship is not taught at foundational level. In government primary and secondary schools, Entrepreneurship per se, is not being taught, but learners are taught practical subjects. In most government primary schools generally, the time allocated for these practical subjects is lower than that allocated to Mathematics and Languages giving the impression that less importance is attached to these practical subjects. The idea behind the introduction of practical subjects into the educational curriculum was to produce job creators and not job seekers. However, the way these practical subjects are taught may not yield the intended results of producing entrepreneurs, as learners are not taken to the ultimate end of setting up businesses which is what entrepreneurship entails. Perhaps the challenge in implementing Entrepreneurship could be the time factor, because, if the whole entrepreneurial process was to be followed, more time would need to be allocated. This is why this researcher is advocating for entrepreneurship to be introduced early in the curriculum so that learners can have adequate time to experience the whole entrepreneurial process. The purpose of this study, therefore, was to find out at what level Entrepreneurship can be introduced in the school curriculum in Zimbabwe to enable learners to go through the whole process of entrepreneurship.

\section{Theoretical framework}

The study is underpinned by the learning theory as postulated by Jerome Bruner. Bruner (1977) asserted that any subject can be taught effectively in some intellectually honest form to any child at any stage of development. He asserted that, if complex material is broken down into its essential ideas, any student can learn any subject matter. One may argue that perhaps 
at an early age, such as primary level, learners might find it difficult to comprehend business language and economic activities. However, Bruner's theory implies that a child can be taught any subject as long as the subject matter is brought down to the child's level.

The theory by John Dewey (1997) is also significant in this study. Dewey opined that education should be child centred and it is, therefore, assumed that implementing Entrepreneurship at an early stage will give learners ample time to go through the whole process of entrepreneurship, acquire the knowledge and the requisite skills which will enable them to set up sustainable businesses later in life. The theory of education for self reliance by Nyerere (1968) as quoted by Kassam (2000) is also applicable to this study, as Nyerere argued that education should prepare an individual to be self reliant. To achieve this, he advocated that practical subjects be given preference over academic subjects. This researcher believes that this is what the educational curriculum in Zimbabwe is trying to achieve. However, if skill of setting up a business is not put to test test while the learner is still at school, under the mentorship of their educators, there could be challenges later in life.

\section{Research objectives}

5.1. Primary objective: this study was conducted to find out when Entrepreneurship can be introduced in the school curriculum.

\subsection{Secondary objectives}

1. To find out whether Entrepreneurship is offered in the school curriculum.

2. To find out at what level Entrepreneurship is introduced in the school curriculum.

3. To establish the level at which Entrepreneurship should be introduced in the school curriculum.

4. To find out how the school curriculum can produce graduates who can set up sustainable businesses.

\section{Materials and methods}

The study employed a case study design which used semi-structured focus group interviews as qualitative data collecting instruments. The case study enabled the researcher to collect in-depth data on the subject under study. This study was conducted in Bulawayo Metropolitan Province in Zimbabwe for convenience (Coopers and Schindler, 2008, p. 397). It was a purely qualitative study and procedures entailed collecting qualitative data on respondents' opinions, perceptions, beliefs, attitudes, motivations and behaviors on when Entrepreneurship can be introduced in the school curriculum. Data were analyzed thematically and according to objectives.

\section{Population and sampling techniques}

Population is the universe of units from which a sample is taken and from which inferences are drawn (Bryman, 2015, p. 715; Cooper \& Schindler, 2008, p. 708). The target population comprised primary and secondary school educators, college lecturers and entrepreneurs from the Bulawayo Metropolitan Province in Zimbabwe.

Respondents were purposively selected. The survey was carried out with 10 primary and 10 secondary school educators of practical subjects, 10 college lecturers and 10 entrepreneurs bringing the total to a manageable population of 40 . The selection of primary educators was based on the fact that these are the people who handle learners at foundational level so they are in a position to gauge what learners at that age are capable of. Secondary school educators were chosen, because they are the link with primary schools and, if Entrepreneurship is introduced at primary level, they would, then, reinforce the ideas that would have been introduced at primary school. Furthermore, the selected secondary school educators were those who teach practical subjects and have relevant knowledge. College lecturers were selected on the basis that they would be the ones training the educators to implement Entrepreneurship. Views were also sought from practising entrepreneurs on when they feel Entrepreneurship should be introduced, since they are the people with the relevant 'hands on' experience.

Respondents were grouped into four focus groups and these were coded as follows. Primary school educators were Focus Group 1, PSEFG 1. Secondary school educators were coded as SSEFG 2, college lecturers, CLFG 3 and entrepreneurs, EFG 4. Entrepreneurs were targeted while attending a workshop on strategic planning where this researcher was the facilitator.

\section{Discussion and findings}

The study sought to find out when Entrepreneurship can be introduced in the school curriculum. Generally, respondents were of the view that Entrepreneurship should be introduced at foundational level, that is, at primary school level, so as to prepare learners' minds for the successful implementation of businesses later in life. Primary School Educators Focus Group 1 argued that: "The foundation for Entrepreneurship should be laid at primary school, 'the catch them young philosophy'. This is a fundamental learning stage where learners are very creative, inquisitive and exploratory. These foundational concepts can, then, be reinforced at high school and at university". These findings tally with views by Udu and Amadi (2013) and North (2002) that the introduction of Entrepreneurship education from primary school level will lay a good foundation for learners". What is implied by these findings is 
that introducing Entrepreneurship at tertiary level could be late as basic entrepreneurial concepts would be better taught at a tender age where learners are at discovery, manipulative and experimental stages. It is at this stage where the foundation can be firmly laid, as Bruner (1977) theorized.

These findings are also in tandem with those of Rwigema (2004) that entrepreneurship is the process of conceptualizing a business idea. Conceptualizing a business idea starts at an early stage, is nurtured until it is developed into a sustainable business venture. The process can start from primary school and be developed through to high school. By the time the learner leaves high school, he or she will have matured into a budding entrepreneur. If the student happens to do the subject at university level, then, there is guarantee that the student is ready to exit into the world as a fully grown entrepreneur assured of setting up a successful business entity. It is difficult to teach an old person new tricks, and the process of becoming an entrepreneur should not be done haphazardly.

It was also established from the study that Entrepreneurship per se is not offered in the school curriculum. As a result, learners are deprived of creating, nurturing and innovating their business ideas. Instead, learners at primary school are taught practical subjects, and the time devoted for these subjects cannot be equated with the time allocated for Mathematics and Languages. The emphasis given to Mathematics and Languages could mean that the curriculum is creating job seekers and not job creators, contrary to the assertions by North (2002) that young people should be educated and trained in the field of Entrepreneurship so that they become job creators, and not job seekers. However, if the learner is taught Entrepreneurship from foundational level, even if a learner drops out of school at Grade Seven, the highest level at primary school, the learner would be in a position to operate a business. This was the philosophy behind Nyerere (1968)'s theory of self reliance.

At high school, learners are taught practical subjects, but the emphasis is on getting students to pass examinations and not so much about imparting entrepreneurial knowledge, as Rwigema (2004) postulated. Most of the respondents were in agreement that, although there is inclusion of practical subjects in the school curriculum, the missing link could be that learners are not taken through the whole process that would, ultimately, lead them to set up businesses.

Some of the perceptions obtained from Secondary School Educators Focus Group 2 are as follows: "Yes, we equip learners with practical skills, but we do not go beyond that. Remember, we are teaching for examinations. The syllabus does not require us to set up businesses. Once the students have mastered the concepts taught, we are quite certain that they will pass the examinations. Mind you, there is ranking of schools according to pass rates. Even if we wanted to teach Entrepreneurship, we would not achieve much within the time that is allocated for practical subjects. The fact that Entrepreneurship has not been introduced at foundational level means that it is not a priority. How much of the learner's creativity and innovation can the educator identify and nurture in such a short space of time?"

These views clearly show that the concept of entrepreneurship has not been embraced in the surveyed schools, thus, indicating that entrepreneurship per se is still a neglected phenomenon. This should be a wakeup call for policy makers and implementers that the educational system still needs to be looked into so as to make graduates relevant, because just by saying Entrepreneurship is being taught without critically reviewing the curriculum will not be of much help. The government is hoping that, through the teaching of Entrepreneurship, the challenge of unemployment will be reduced, yet, the output that is being churned out might not necessarily address the market demands.

Secondary School Educators Focus Group 2 (SSEFG 2) further asserted that: "Instead of School Development Councils (SDCs) wholly running business projects in schools, they should engage learners too. They can start off by conducting entrepreneurial projects with learners and eventually handover the projects to learners to run. Afternoons can also be utilized for entrepreneurial projects by high school learners. This can start off as a pilot project and, then, be rolled out on a full scale when desired results show. In order to achieve all this, there is a need for involvement of various stakeholders such as educationists, policy makers. Administrators in schools and parents need to be conscientized on the importance of inculcating the right attitudes in learners about the importance of Entrepreneurship. Learners should also be exposed to the real world of business by conducting field trips, visit industrial areas, agricultural shows and business expos".

Entrepreneurs Focus Group 4 (EFG 4) concurred with the views that Entrepreneurship should be embedded in the teaching of practical subjects. These were their views: "Educators should not only equip learners with practical skills, but also should involve them in comprehensive entrepreneurial activities. Then, as an educator, you can be certain that you have prepared someone for future life". Entrepreneurs Focus Group 4 went further to say, "You can only tell whether appropriate skills have been inculcated in learners when you see them put the skills into practice. We are encountering challenges in business, because we were never mentored while still at school. Such an 
opportunity would not only motivate learners to come up with unique business ideas, a skill necessary in creating a competitive advantage in business, but also give educators a chance to assess how well learners have grasped entrepreneurial concepts".

The younger entrepreneurs in Entrepreneurs Focus Group 4 said that, although they did practical subjects at school, the lessons were purely instructional and teacher centred. They were not given the opportunity to come up with their own ideas, as the emphasis was on passing examinations. Entrepreneurs Focus Group 4 (EFG 4) expressed the following sentiments: "At primary school, educators would simply tell us what to do during practical subjects. There was a lot of drilling and rote learning. Our parents also in a way contributed to our plight, because they only wanted us to be doctors, nurses or educators and look for formal employment after completing our studies". These findings reveal that the education system was geared towards white collar jobs which are not what our market needs today. Our market needs job creators, and not job seekers.

College Lecturers Focus Group 3 (CLFG 3) concurred that students should be taught Entrepreneurship while still young: "Even the Bible in Proverbs 22 verse 6 says, "Train a child in a way that he should go, so that when he is grown, he will not depart from it". These findings that learners should be taught Entrepreneurship early corroborate Bruner (1977)'s theory that a child can be taught new concepts at any stage. As previously pointed out, one might argue that, at primary school, learners are still too young to conceptualize business ideas, but Bruner (1977) asserts that no concept is too difficult to learn as long as it is brought down to the learner's level.

\section{Conclusion}

Based on the findings of the study, Entrepreneurship should be introduced at an early age to lay a solid foundation in learners that will help them to come up with creative and innovative ideas for use later in life. The study further concludes that there is a gap between the drive by the government towards promoting Entrepreneurship and the actual implementation of Entrepreneurship. Proper timing in introducing the subject appears not to have been critically considered. Early introduction of the subject will enable learners to learn without limits.

The study was conducted in government primary and secondary schools and excluded private schools. A potential area for further research would be to find out what the situation in private schools is, for comparative purposes.

\section{Recommendations}

Considering how vital Entrepreneurship is in Zimbabwe today, policy makers should consider the introduction of the subject at primary school level and accord it the same importance in the school curriculum just like Mathematics and Languages. If Entrepreneurship cannot be taught as a stand alone subject because of the time factor, some afternoons can be utilized for entrepreneurial activities. Entrepreneurship should be taught in such a way that even dropouts at primary, secondary or tertiary level can be turned into meaningful citizens who can set up and run their own businesses. In addition, suitable infrastructure such as incubation centres where learners will conceptualize their business ideas should be established in schools.

\section{References}

1. Agboola, A.K. (2014). Entrepreneurship Education and Youth Unemployment Problem in Nigeria: Do Facilities On The Ground Commensurate Course Delivery? Academic Research International, 5 (4), pp. 93-104.

2. Akpan, E.I., Sunday, A.E. and Ele, A.A. (2012) Entrepreneurship Education Policy: An Intervention Strategy For Economic Development In Nigeria, Business and Entrepreneurship Journal, 1, pp. 101-110.

3. Ali, M.M. (2015). Borrower's Perception: SMBEs Financing by the Banking Sector Of Bangladesh. Daffodil International University, Journal Of Business and Economics, 9 (1), pp. 53-76.

4. Arasti, Z., Falavarjani, M.K. and Imanipour, N. (2012). A Study of Teaching Methods in Entrepreneurship Education for Graduate Studies. University of Tehran. Tehran.

5. Brown, C. (2000). Money, Power, Respect, Black Enterprise, 30, pp. 98-102.

6. Bruner, J. (1977). The process of education. Cambridge. Havard University Press.

7. Bryman, A. (2015). Social research methods. $4^{\text {th }}$ edition. Oxford. Oxford University Press.

8. Cooper, D.R. and Schindler, P. (2008). Business Research Methods. McGraw Hill. International Edition.

9. Dewey, J. (1997). Experience and Education. MacMillan.

10. Fatoki, O. and Chindoga, L. (2011). An Investigation into the Obstacles to Youth Entrepreneurship in South Africa, International Business Research, 4 (2), pp. 161-169.

11. Isaacs, E., Visser, K. and Brijlal, P. (2007). Entrepreneurship education and training at the Further Education and Training (FET) level in South Africa, South African Journal of Education EASA, 27, pp. 611-629.

12. Kassam, Y. (2000). Julius Kambarage Nyerere, International Bureau of Education. UNESCO.

13. Moyana, T.T. (1986). Education, Liberation \& the Creative Art. Harare: Zimbabwe Publishing House.

14. Moyo, M.K. (2013). Interview with a former high school headmaster. Bulawayo. (Author in possession of notes).

15. Nkechi, A. Ikechukwu, E.J. and Ukah, F.O. (2012). Entrepreneurship development and employment generation in 
Nigeria: Problems and Prospects, Universal Journal of Education and General Studies, 1 (4), pp. 88-102.

16. Nieman, G., Hough, J. \& Nieuwenhuizen, C. (2014). Entrepreneurship. Pretoria: Van Schaik Publishers.

17. North, E. (2002). A decade of entrepreneurship education in South Africa, South African Journal of Education, EASA Science Africa, 22 (1), pp. 24-27.

18. Nyathi, P. (2013). Interview with the author, historian and former headmaster. Bulawayo. (Author in possession of notes.)

19. Nziramasanga, C.T. (1999). Zimbabwe Report of the Presidential Commission of Inquiry into Education and Training. (August, 1999).

20. Rwigema, H. (2004). Advanced Entrepreneurship. Cape Town: Oxford University Press.

21. Salami, C.G.E. (2011). Entrepreneurial Interventionism and Challenges of Youth Unemployment in Nigeria, Global Journal of Management and Business Research, 11 (7), pp. 16-24.

22. Udu, C.S. \& Amadi, U.P.N. (2013). Integrating Basic Entrepreneurship Studies into Primary Education Curriculum: Platform for Sustainable National Development, Academic Journal Of Interdisciplinary Studies, 2 (5), pp. 69-74.

23. Zvobgo, R.J. (1994). Colonialism and Education in Zimbabwe. Harare: Space Books. 